\title{
Membedah Mitos Kapuhunan Di Kalimantan Dari Aspek Psikologi
}

\author{
Ajeng Anggoro Putri \\ Fakultas Psikologi Universitas Surabaya \\ ajenganggoroputri@gmail.com
}

\begin{abstract}
In Indonesia, there are many myths from various regions. In Kalimantan, there is a myth that called kapuhunan. Kapuhunan is bad luck or disaster that occurs when we reject the food offered or do not have time to eat the food that has been served. Myth gives people something to be trusted and feared; myth also bring hope to humans. If there's no myth, there's no value to regulate the activities of human life. The negative perceptions of the kapuhunan made the local people anxious if they did not have time to eat the food that had been served. One process of the occurrence of anxiety is the perception of situation. It is important to know about the process of forming perceptions and anxiety can change negative perceptions into positive perceptions. The myth that we believe can form perceptions and anxiety.
\end{abstract}

Key words : kapuhunan; perception; anxiety

\begin{abstract}
Abstrak
Di Indonesia banyak sekali mitos-mitos dari berbagai daerah. Di Kalimantan ada sebuah mitos bernama kapuhunan. Kapuhunan adalah kesialan atau bencana yang kita alami ketika kita menolak makanan yang ditawarkan atau tidak sempat memakan makanan yang telah di hidangkan. Mitos memberikan manusia sesuatu untuk dipercayai dan ditakuti; mitos juga membawa harapan bagi manusia. Jika tidak ada mitos, tidak ada nilai untuk mengatur aktivitas kehidupan manusia. Persepsi negatif dari mitos kapuhunan membuat masyarakat setempat menjadi was-was dan mudah cemas jika mereka tidak sempat memakan makanan yang telah dihidangkan. Salah satu proses terjadinya kecemasan adalah perception of situation. Pentingnya mengetahui proses pembentukan persepsi dan kecemasan dapat merubah persepsi negatif menjadi persepsi positif. Mitos yang kita percaya membentuk persepsi dan membuat munculnya kecemasan.
\end{abstract}

Kata kunci : Kapuhunan, persepsi, kecemasan 


\section{Pendahuluan}

Mitos merupakan suatu cerita suci yang hampir selalu ada dalam setiap budaya masyarakat dimana pun. Berbagai penelitian, terutama yang dilakukan oleh orang-orang Barat, menunjukan bahwa mitos selalu muncul dalam berbagai aktivitas sosial keagamaan masyarakat, terutama pada masyarakat tradisional atau masyarakat pre literate. Sebagian besar masyarakat dilingkupi dengan mitos-mitos yang mempunyai nilai sakral bagi penganutnya. Baik masyarakat tradisional (masyarakat preliterate) maupun masyarakat modern, selalu menggunakan mitosmitos yang mempunyai nilai sakral bagi penganutnya, menggunakan mitos-mitos yang disakralkan sebagai simbol pengukuhan dan otoritas. Dalam melakukan beragam aktivitas sosial keagamaan, bahkan aktivitas ekonomi dan politik, selalu ada mitos yang dimunculkan untuk membuat masyarakat yakin bahwa yang dimitoskan mempunyai nilai sakralitas yang tidak boleh diremehkan apalagi diruntuhkan dan dihancurkan.

Banyak ahli berpendapat bahwa manusia, baik sebagai individual maupun sebagai kelompok, tidak dapat hidup tanpa mitos atau mitologi. Artinya bahwa keberadaan mitos sangat vital dan penting bagi eksistensi hidup manusia, terutama dalam hal yang berkaitan dengan mitologi yang bersifat keyakinan dan keagamaan. (Humaeni, 2012). Mitos menceritakan mengenai kepercayaan terhadap kekuatan yang lebih besar dari manusia, dari mana manusia berasal, dan bagaimana interaksi yang seharusnya dilakukan oleh manusia dengan kekuatan yang lebih besar ini. Nilai yang dibawa oleh mitos juga mengandung kebenaran. Walaupun manusia sudah hidup di jaman modern mitos masih memegang peranan penting dalam kehidupan manusia. Mitos memberikan manusia sesuatu untuk dipercayai dan ditakuti; mitos juga membawa harapan bagi manusia. Jika tidak ada mitos, tidak ada nilai untk mengatur aktivitas kehidupan manusia.

Nilai-nilai utama mitos ditambah dengan persepsi modern inilah yang akan diturunkan ke masyarakat, sehingga masyarakat memiliki persepsi baru dan berujung pembuatan cerita mitos baru (Angeline, 2015). Menurut Wilkinson dan Philip (2007) mitos mengatur aktivitas sehari-hari manusia baik disadari maupun tidak, dan mitos juga menjadi template mengenai apa yang baik dan buruk di 
suatu masyarakat. Walaupun mitos selalu berkembang, nilai-nilai inti yang disampaikan selalu sama dan berupa pedoman agar manusia dapat survive di lokasi atau situasi tertentu.

Di Indonesia banyak sekali mitos-mitos dari berbagai daerah. Di Sumatera Barat ada mitos Malin Kundang yang memiliki makna bahwa sebagai anak kita tidak boleh durhaka kepada orang tua kita meskipun kita telah menjadi orang sukses. Di Jawa ada mitos bahwa anak gadis tidak boleh duduk didepan pintu, nanti jodohnya susah, padahal sebenarnya kalau dipikir secara logika, maksudnya tidak boleh duduk didepan pintu karena dapat menghalangi orang yang ingin keluar masuk rumah. Di masyarakat Bugis, ada mitos jika duduk diatas bantal nanti bisa bisulan, padahal sebenarnya memang bantal jika diduduki bisa rusak, dan bantal biasanya memang untuk kepala. Di Bali ada mitos yang ditakuti oleh para pasangan yang berpacaran dimana mereka tidak boleh ke Pura Tanah Lot bersama pacar karena jika mereka kesana, hubungan mereka bisa rusak atau berantakan. Dari beberapa contoh mitos diatas makna dari mitos-mitos tersebut sesuai dengan definisi mitos pada beberapa penelitian yaitu dimana mitos membentuk persepsi pada masyarakat, mitos mengatur kehidupan sehari-hari, dan juga mitos menjadi hal yang dipercayai dan ditakuti. Mitos membuat kita berperilaku sesuai dengan norma dan budaya masyarakat setempat. Oleh karena itu peneliti ingin membahas mitos disalah satu pulau di Indonesia yaitu Pulau Kalimantan. Mitos yang akan dibahas adalah mitos kapuhunan yang sampai saat ini masih dipercaya oleh masyarakat setempat.

\section{Hasil dan Pembahasan}

Di Kalimantan terdapat mitos yang sangat melekat pada masyarakat Kalimantan, dimana mitos ini sudah membentuk perilaku masyarakat di Kalimantan. Mitos yang dipercayai dan ditakuti oleh masyarakat setempat yaitu kapuhunan. Kapuhunan berasal dari kata "kepohonan" didalam bahasa banjar, huruf e=a, huruf $\mathrm{o}=\mathrm{u}$. Kapuhunan sendiri berarti suatu kejadian dimana seseorang dalam tubuhnya dirasuki, dimasuki atau diganggu oleh makhluk halus penunggu pohon tertentu sehingga menyebabkan orang tersebut bertingkah laku tidak 
sewajarnya (Kawi, 2002). Namun pada saat ini persepsi masyarakat Kalimantan mengenai kapuhunan telah berubah. Saat ini kapuhunan diartikan sebagai kesialan atau tulah yang kita peroleh. Seseorang akan mendapat celaka atau musibah apabila tidak memakan makanan yang ditawarkan, atau apabila tidak sempat makan sesuatu yang sudah diinginkan atau sudah dihidangkan (Faisal, 2018).

Mitos kapuhunan sudah menjadi budaya turun menurun pada masyarakat Kalimantan, mitos kapuhunan sendiri tersebar dari mulut ke mulut. Masyarakat Kalimantan yang mempercayai mitos ini pada umumnya pernah mengalami katulahan atau kesialan dari kapuhunan itu sendiri oleh karena itu persepsi mereka terhadap kapuhunan menjadi kuat. Walgito (1980) mengatakan bahwa persepsi merupakan suatu proses yang didahului oleh proses penginderaan, yaitu proses diterimanya stimulus oleh individu melalui alat indera atau juga disebut proses sensoris. Namun proses itu tidak berhenti begitu saja, melainkan stimulus tersebut diteruskan dan proses selanjutnya merupakan proses persepsi.

Proses persepsi menurut Schermerhorn dkk (1994) ada 4 tahap, yaitu: 1) perhatian dan seleksi, pada tahap ini informasi yang diterima dipilih secara selektif, individu akan memutuskan informasi mana yang akan diterima dan diabaikan. Ketika individu mendapatkan informasi mengenai kapuhunan individu tersebut akan memilih apakah ia akan menerima atau mengabaikan informasi tersebut. Mungkin pada awalnya ia akan mengabaikan informasi terkait kapuhunan namun ketika ia sering mendapat informasi tersebut dari banyak orang ia mulai bertanya tanya, apa itu kapuhunan dan ia juga akan menyimpan informasi tersebut; 2) organisasi, pada tahap ini informasi yang telah diseleksi diorganisasi dalam bentuk schema, schema adalah kerangka kognitif yang menggambarkan pengetahuan yang diorganisasi dengan pemberian konsep atau stimulus yang dibagun melalui pengalaman.

Ketika individu melihat kejadian dari kapuhunan, atau mengalami hal tersebut pada dirinya sendiri, individu akan membentuk schema bahwa kapuhunan adalah kesialan/musibah yang terjadi ketika kita menolak tawaran makanan atau minuman atau ketika kita menginginkan suatu makanan kita tidak sempat memakannya; 3 ) interpretasi, pada tahap ini individu akan mencoba untuk 
memperoleh jawaban tentang makna dari informasi tersebut. Pada tahap ini individu akan mencoba mencari tahu apakah mitos kapuhunan itu benar adanya atau hanya sebuah mitos yang tidak ada artinya. Ketika mitos itu benar terjadi maka persepsi tentang mitos kapuhanan terbentuk dalam pikirannya; 4) pencarian kembali (retrieval), yaitu tahap dimana mencari kembali informasi yang telah terskema dan terorganisir dengan baik untuk digunakan kembali. Pada tahap ini individu akan mengingat kembali informasi mengenai mitos kapuhunan ketika ada orang yang menawarkan makanan atau minuman atau ketika ia terlupa memakan makanan yang ia inginkan. Jadi, proses-proses inilah yang membentuk persepsi mengenai kapuhunan pada masyarakat Kalimantan, dan juga mitos kapuhunan ini sendiri merupakan mitos turun menurun dari nenek moyang sehingga mitos ini menjadi sangat kuat melekat pada masyarakat Kalimantan.

Secara tidak langsung persepsi kapuhunan yang diterima dari lingkungan membuat seseorang akan bersikap mudah merasa cemas, was-was dan takut ketika menyadari telah terlupa makan ataupun minum yang telah ditawarkan. Ia akan cenderung bersikap negatif dalam menilai suatu objek yang dirasa merupakan dampak dari kapuhunan. Gail W. Stuart (2006: 144) memaparkan "kecemasan adalah kekhawatiran yang tidak jelas dan menyebar, yang berkaitan dengan perasaan tidak pasti dan tidak berdaya". Kecemasan menurut Roger adalah sebagai keadaan ketidaknyamanan atau ketegangan yang tidak diketahui sebabnya.

Ketika orang semakin tidak menyadari ketidakkongruenan antara pengalaman dan persepsi dirinya, kecemasan berubah menjadi ancaman terhadap konsep diri kongruen dan terjadi pergeseran konsep diri kongruen. Ada 5 proses terjadinya kecemasan (Spielberger, 1983):

1) Evaluated Situation, adanya situasi yang mengancam secara kognitif sehingga ancaman ini dapat menimbulkan kecemasan. Misalnya ketika kita hendak memakan atau meminum suatu makanan/minuman namun kita tidak sempat memakannya secara tidak sadar kita memikirkan makanan/minuman.

2) Perception of situation, situasi yang mengancam diberi penilaian oleh individu, dan biasanya penilaian ini dipengaruhi oleh sikap, kemampuan dan 
pengalaman individu. Ketika kita melihat sendiri dampak dari kapuhunan itu maka secara tidak langsung kita membuat persepsi negatif pada kapuhunan, hal ini juga dipengaruhi oleh orang sekitar kita yang juga membenarkan bahwa musibah yang terjadi pada orang yang menolak makanan/minuman yang telah dihidangkan atau tidak sempat memakan/meminumnya itu adalah makna dari kapuhunan.

3) Anxiety State of Reaction, individu menganggap bahwa ada situasi berbahaya, maka reaksi kecemasannya akan timbul. Komplesitas respon dikenal sebagai reaksi kecemasan sesaat yang melibatkan respon fisiologis seperti denyut jantung dan tekanan darah. Ketika kita tidak sempat memakan/meminum makanan yang telah dihidangkan, kita merasa cemas, takut terjadi kapuhunan pada diri kita.

4) Cognitive Reappraisal Follows, individu kemudian menilai kembali situasi yang mengancam tersebut, untuk itu individu menggunakan pertahanan diri (defense mechanism) atau dengan cara meningkatkan aktivitas kognisi atau motoriknya. Ketika kita takut akan terjadi dampak dari kapuhunan tersebut, kita mencoba berdoa agar tidak terjadi musibah pada diri kita. Bisa juga kita berfikir positif atau memberikan sugesti positif kepada pikiran kita.

5) Coping, individu menggunakan jalan keluar dengan menggunakan defense mechanism (pertahanan diri) seperti proyeksi atau rasionalisasi. Ketika kita takut akan dampak dari kapuhunan maka kita mencoba mengalihkan pikiran, kita berfikir bahwa kapuhunan itu hanya mitos, atau kita mencoba untuk tidak memikirkan makanan/minuman dan dampak dari kapuhunan tersebut. Dari beberapa proses kecemasan diatas, faktor utama kecemasan adalah faktor kognitif, yaitu persepsi kita pada makna sebuah mitos. Kita merasa cemas karena takut terkena musibah akibat dari kapuhunan. Jika kita tidak memikirkan makna dari kapuhunan kita bisa saja tidak cemas, atau kita membuat pikiran positif mengenai makna dari kapuhunan dan bisa jadi musibah itu tidak menimpa kita. 


\section{Kesimpulan}

Kapuhunan adalah tulah atau kesialan yang kita peroleh jika kita tidak memakan makanan yang ditawarkan atau jika kita tidak sempat memakan makanan yang kita inginkan. Persepsi negatif dari mitos ini membuat masyarakat setempat menjadi was-was dan mudah cemas jika mereka tidak sempat memakan makanan yang telah dihidangkan. Kecemasan yang mereka rasakan dipengaruhi oleh pikiran mereka sendiri. Jika kita membuat pikiran positif mengenai makna dari kapuhunan bisa jadi musibah itu tidak menimpa kita.

\section{DAFTAR PUSTAKA}

Angeline, (2015), Mitos dan budaya, Jakarta, Humaniora Vol. 6 No. 2.

Faisal, (2018), Persepsi Masyarakat Banjar Terhadap Kapuhunan, Psycho Idea, No. 2.

Humaeni, (2012), Makna Kultural Mitos dalam Budaya Masyarakat Banten, Antropologi Indonesia, vol. 33 no. 3.

Kawi. D, (2002), Bahasa Banjar Dialek dan Subdialeknya, Banjarmasin: PT. Grafika Wangi Kalimantan.

Schermerhorn, Hunt et al, (1994), Managing Organizational Behavior, hal : 153155 Spielberger, 1983, State-trait Anxiety Inventory Manual.

Walgito, (1980), Pengantar Psikologi Umum, Penerbit Andi, Yogyakarta, hal. 99103 